\title{
Trichosporon asahii
}

National Cancer Institute

\section{Source}

National Cancer Institute. Trichosporon asahii. NCI Thesaurus. Code C114272.

A yeast in the phylum Basidiomycota. This species is round to oval shaped, with budding yeast-like cells, produces true hyphae forming cylindrical arthroconidia, and hydrolyzes urea. T. asahii is a common soil inhabitant and colonizes the skin and gastrointestinal tract of humans. It may cause superficial infections, disseminated trichosporonosis in immunocompromised individuals, fungemia and fatal septic shock. 